\title{
SOU DESTE CHÃO! MARCAS DE FERRAR GADO, PRÁTICAS E (IN)SENSIBILIDADES NA EDUCAÇÃO DO HOMEM DO NORDESTE
}

Iranilson Buriti de Oliveira ${ }^{1}$

\author{
"Janelas e portas sujas \\ De riscos e garatujas \\ Monogramas e sinais; \\ A fogo, acima, outras marcas \\ São ferros de patriarcas \\ Que não prevalecem mais" \\ Othoniel Menezes.
}

\section{Introdução}

Ao longo das décadas iniciais do século XX, foram sendo desenhados e redefinidos modelos e estereótipos para a família que habita a cartografia espacial denominada Nordeste. Uma vez criada a região ${ }^{2}$, o discurso regionalista se preocupou em fabricar ou reproduzir um modelo comportamental para o nordestino. Homens e mulheres desse território receberam uma sobrecarga de perfis que os projetaram para outras regiões brasileiras ${ }^{3}$. Nesse contexto histórico de emergência da região Nordeste, se constitui um campo discursivo e de produção cultural e regional no qual retóricas e imagens masculinas e sobre o masculino são utilizadas cotidianamente por políticos, romancistas, jornalistas e outros escritores, divulgando determinadas coordenadas discursivas para além das fronteiras regionais. Símbolos, marcas, pistas, emblemas, signos que elaboram uma dada visibilidade para o masculino e para o feminino no Nordeste.

Essa produção discursiva e identitária faz parte de um agenciamento pedagógico que envolve múltiplos sujeitos. No ambiente familiar, no qual se tecem performances para as crianças e os jovens, essa etapa formativa da infância e da juventude se relaciona com a paternidade e o trabalho doméstico e, posteriormente, em dois

\footnotetext{
${ }^{1}$ Doutor em História pela Universidade Federal de Pernambuco. Realizou estágio pós-doutoral junto à Fundação Casa de Oswaldo Cruz em 2008. Professor Associado da Unidade Acadêmica e do Programa de Pós-Graduação em História da Universidade Federal de Campina Grande. Professor Colaborador do Programa de Pós-Graduação em Educação da Universidade Federal da Paraíba. Pesquisador 2 do CNPq. E-Mail: <iburiti@yahoo.com.br>.

${ }^{2}$ Sobre a criação do Nordeste como região independente do Norte brasileiro, o livro de Albuquerque Júnior traz uma valiosa contribuição à historiografia brasileira sobre essa temática. Esse novo espaço que emerge relaciona-se com a reorganização discursiva sobre a região. ALBUQUERQUE JR., Durval Muniz de. O engenho antimoderno: a invenção do Nordeste e outras artes. 2 ed. São Paulo: Cortez, 1998.

${ }^{3}$ No Brasil, cada cultura regional construiu seus próprios critérios de definição de masculinidade, a exemplo do gaúcho, do nordestino, do pescador. Isso significa que as exigências que se impõem aos rapazes das diferentes regiões não são as mesmas.
} 
espaços sociais complementares: o trabalho e a diversão. Porém, é importante registrar que, para a constituição das identidades masculinas, é necessário levar em consideração outros aspectos, tais como: 1) a rede discursiva (ciência, religião, filosofia, cultura, cultura escolar, etc.); 2) as representações de gênero; 3) as instituições de socialização (família, grupo de pares, escola, meios de comunicação, comunidades religiosas, trabalho e vida pública); e 4) as relações sociais em que os sujeitos produzem representações de gênero ${ }^{4}$.

Um conjunto de símbolos falocráticos foi utilizado para peculiarizar a macheza desse homem, sendo um deles a marca de ferrar gado, pois somos sabedores que é na linguagem do corpo, nas práticas discursivas e extradiscursivas do cotidiano que os conceitos de família, de masculino e de feminino são primeiramente construídos e compreendidos pelos sujeitos. $\mathrm{O}$ ato de ferrar gado pode ser visto, no contexto mais amplo da região em questão, como um espaço no qual as habilidades masculinas podem ser exibidas pelos homens em ocasiões públicas, como um ritual que se nutre de fórmulas "masculinizadoras", como um lugar de lutas no qual se confrontam referentes simbólicos, como um encontro de poderes exibido pela tradição dos ferros usados no ato da marcação. É, também, uma forma de gestualidade, de disposição do corpo frente aos olhos de mulheres e de homens, já que estes, rotineiramente, elaboram sua identidade masculina ${ }^{5}$ não somente frente às mulheres, mas principalmente, diante de outros homens ${ }^{6}$. Sua relevância reside na capacidade ritual, já que este é uma prática secular desde o período do Brasil colonial, presente no processo de ocupação territorial sertanejo, uma tradição inventada ${ }^{7}$ marcada pela teatralidade do ato de marcar, como veremos neste artigo.

\section{Hastes Polifônicas: as Marcas de Ferrar Gado e as Narrativas Masculinas}

A marca de ferrar gado possui toda uma significação de identidade familiar e de pertencimento regional, de reconhecimento do nome, do sangue, dos dispositivos de poder. Funciona como uma etiqueta de pertencimento familiar. A marca impressa, como assinala Paes, com o tempo, "passa a fazer parte do couro do animal, como se ali tivesse nascido, possuindo uma representatividade que vai muito além de uma cicatriz" ${ }^{8}$. No corpo da rês, tais marcas tornam-se referências familiares e culturais,

${ }^{4}$ TROYA, María del Pilar de. "Clase media de la ciudad de Quito". In: ANDRADE, Xavier \& HERRERA, Gioconda. Masculinidades en Ecuador. Quito: Flacso, 2001.

${ }^{5}$ Compreendemos que a masculinidade e a identidade masculina estão em constante transformação, resultado das relações socioculturais, econômicas, políticas e religiosas.

${ }^{6}$ ANDRADE \& HERRERA, Masculinidades en Ecuador.

${ }^{7}$ A invenção da tradição é, conforme Hobsbawn e Ranger, uma estratégia discursiva que se utiliza de tradições que parecem ou alegam ser antigas. Neste sentido, essas tradições se manifestam na forma de práticas, ritualísticas ou simbólicas, com o intuito de propor valores e critérios de comportamento centrados na repetição quase obrigatória, com vistas a assegurar a perpetuação de um passado histórico adequado. HOBSBAWM, Eric J. "Introdução: a invenção das tradições". In: __ \& RANGER, Terence (orgs.). A invenção das tradições. Tradução de Celina Cardim Cavalcante. 8. ed. São Paulo: Paz e Terra, 2012, p. 7-8.

${ }^{8}$ PAES, Daniella Lira Nogueira. Sob os signos das boiadas: as marcas de ferrar gado que povoam o sertão paraibano. Dissertação (Mestrado Profissional em Preservação do Patrimônio Cultural). Instituto do Patrimônio Histórico e Artístico Nacional. Rio de Janeiro, 2012. 
sinais "que identificam sua importância para a sociedade e, consequentemente, para a cultura do povo sertanejo" 9 .

As marcas de ferrar são gramáticas de poder e de saber. São hastes polifônicas que emitem os sons dos corpos: do corpo do homem e do corpo da rês; do corpo familiar e do corpo regional. No dia marcado para ferrar o gado, uma festa é realizada, com zoada, mangação, alegria, gritos de avisos e cuidados, aplausos, "entremeados com o tropel e o berro-dor da rês ferrada"10. Como em qualquer outro ritual, os "vaqueiros entram em cena e, de forma que parece ser calculada, laçam o animal, prendem-no e, com o ferro em brasa, marcam-no para sempre". Para Paes, a "ferra é um dia de festa que o sertanejo aprendeu a comemorar, mas pode parecer uma verdadeira tortura para quem não está acostumado com as "coisas do sertão""11.

A ferra, ainda hoje, é uma tecnologia rudimentar que demarca fronteiras de gênero, que sonoriza as masculinidades do nordestino, masculinidade compreendida não como algo dado, mas como um processo, como um objetivo social e cultural a ser alcançado, não como uma coisa pronta ou adquirida, ou seja, o que os homens dizem, pensam e fazem contribuem para definir e distinguir a si mesmos como homens ${ }^{12}$.

Ser um coronel ou grande fazendeiro é muito mais que possuir dinheiro e propriedades, é saber utilizá-los estrategicamente para propagar toda uma economia de poder, um emblema de prestígio, de reconhecimento do capital simbólico. $\mathrm{O}$ código de honra não era apenas o sangue familiar e o sobrenome que carregava na certidão de batismo. Estendia-se pelo sangue e pelo couro dos animais que lhe pertenciam. O ferro de marcar gado também demarcava um território privado e afetivo; forjava uma delimitação geográfica estampada no couro da rês; criava uma cartografia de poder e de riqueza em torno da marca e do dono da mesma: "A marca é um sinal de propriedade. O dono da rês imprime a ferro em brasa, no couro dela, sua marca individual. Ali fica caracterizada a propriedade"13.

As letras e os desenhos que simbolizam famílias tidas como tradicionais se constituem em uma herança de "nobrezas sertanejas", a perpetuação de um tipo de patrimônio afetivo, rastros de poder e de tradição, fios de solidariedade entre vizinhos que se respeitavam através das marcas de ferrar, memórias coletivas que se traduzem em hábitos de vestimentas (gibão, chapéu de couro, peitoral, sandálias, perneiras), alimentícios e linguísticos, com um palavreado ancorado nas metáforas rurais e religiosas, bem como na fusão de elementos da língua portuguesa e da espanhola.

\footnotetext{
${ }^{9}$ PAES, Sob os signos das boiadas..., p. 12.

${ }^{10}$ FARIA, Lamartine de. Ferros de Ribeiras. Mossoró: Fundação Vingt-Un Rosado, 1982, p. 29.

${ }^{11}$ Essa é a principal festa da fazenda. Outras festividades caíram em desuso, a exemplo das "festas de apartação" e o uso do ferro da ribeira, pelo fato de, praticamente, não se criar mais o gado a solta. Paes argumenta que as "festas serviam para juntar os rebanhos que se misturavam pelas fazendas e distribuí-los aos seus respectivos donos, sendo, em seguida, finalizadas com comida, bebida $e$ vaquejadas. Com o intuito de separar e identificar seus rebanhos espalhados pela redondeza, os fazendeiros esperavam o fim do inverno, para promover as grandes "festas de apartação". Já o ferro da ribeira, era usado como uma segunda marca que representava a região geográfica de origem do animal, complementando sua identificação. Com o uso de cercas, os campos indivisos diminuíram e essas práticas foram perdendo o sentido". PAES, Sob os signos das boiadas..., p.13-14.

${ }^{12}$ ANDRADE \& HERRERA, Masculinidades en Ecuador, p. 14.

${ }^{13}$ MAIA, Virgílio. De iniciação à heráldica às marcas de ferrar gado. Recife: O Curumim, 1984, p. 31.
} 
A personagem Fabiano, do romance de Graciliano Ramos, Vidas Secas, sabia o significado identitário que o ferrão representava ${ }^{14}$. Uma rês perdida sem marca de ferro não levava o nome do patriarca, não podia ser identificada, já que não havia signo de propriedade. Uma égua que não fora ferrada representava um perigo para o proprietário, pois sem a marca, qualquer um podia ser o dono:

Baleia voou de novo entre as macambiras, inutilmente. As crianças divertiram-se, animaram-se, e o espírito de Fabiano se destoldou. Aquilo é que estava certo. Baleia não podia achar a novilha num banco de macambira, mas era conveniente que os meninos se acostumassem ao exercício fácil - bater palmas, expandir-se em gritaria, seguindo os movimentos do animal. A cachorra tornou a voltar, a língua pendurada, arquejando. Fabiano tomou a frente do grupo, satisfeito com a lição, pensando na égua que ia montar, uma égua que não fora ferrada nem levava sela. Haveria na caatinga um barulho medonho. ${ }^{15}$

A cerimonialização de ferrar, associada aos desenhos, ao cheiro do pelo, do couro $e$ da carne queimada, atesta também um ritual de masculinidade ${ }^{16}$ e de dominação masculina. O ferro do fazendeiro era uma estampa que demarcava as fronteiras das relações de gênero e afirmava o domínio sobre o outro. A marca-signo, embora simbolicamente pertencesse à família, estava representada pelo nome do patriarca. Era muito mais que uma marca familiar: era um símbolo do ser homem, do ser dominador. Não apenas produzia e reproduzia a estrutura de dominação masculina no cenário cotidiano, mas tornava-se parte do sistema de crenças que articulava a sociedade, delineava o território sexual e produzia uma interiorização gradual mediante todo um processo de subjetivação e de socialização de códigos que se inicia nos primeiros anos da infância: "O gesto de ferrar um boi, aquele movimento todo, o corre-corre, os desenhos das marcas [...] parecem ficar indelevelmente guardados na lembrança de quem era menino, decerto encarrapitado no gato da porteira do curral, presenciou aquilo tudo. E aqui acolá essa recordação aflora" ${ }^{17}$.

$\mathrm{Na}$ marca de ferrar gado estavam contidos os sinais de propriedade, de prestígio social e da cultura masculina dominante. A marca, ao mesmo tempo em que afirmava o seu dono, negava e reprimia a figura feminina, silenciada, quase sempre, no contexto da ferração. O nome da família era o do pai, do marido, do homem,

${ }^{14}$ Segundo Ariano Suassuna, um dos maiores pesquisadores das marcas de ferrar gado, cada uma das insígnias oculta um significado simbólico, muito presente em décadas passadas, mas depois paulatinamente esquecidas. Cf. SUASSUNA, Ariano. Ferros do Cariri: uma heráldica sertaneja. Recife: Guatiba, 1974.

${ }^{15}$ RAMOS, Graciliano. Vidas secas. 76. ed. Rio de Janeiro: Record, 1998.

${ }^{16}$ Masculinidade, no debate atual, pode ser compreendida como um conjunto de noções superpostas e não necessariamente correspondentes uma com as outras. Quando distintos autores invocam conceitos tais como "masculinidade" (no singular ou no plural), "machismo", "identidade masculina", "hombridade", "virilidade" e "papel masculino", diferentes possibilidades analíticas se abrem. ANDRADE \& HERRERA, Masculinidades en Ecusdor, p.14

${ }^{17}$ MAIA, De iniciação à heráldica..., p. 27. 
enquanto a mulher era apenas uma imagem refletida no ferrão. A linguagem simbólica, dessa forma, desempenha um papel de fundamental importância na definição e na conservação da genealogia da masculinidade, delimitando e limitando os espaços, contribuindo, também, para a construção da subjetividade feminina ${ }^{18}$.

A família, então, era cotidianamente cercada por uma linguagem que delineava os papéis de gênero, por um exercício pedagógico que circunscrevia homens e mulheres em esferas diferentes. A criança já era educada inserida num cotidiano favorável à estrutura de dominação do "cabra da peste", aprendendo, desde cedo, a linguagem do machismo, do mandonismo, da superioridade. Essa forma de linguagem adestrava eficazmente a mente e os corpos das crianças, funcionando como um instrumento de "socialização da criança às formas tradicionais de visão de mundo de um determinado grupo, o que, em grande parte, está ligado ao fato de ser a linguagem um importante indicador e reforçador de valores e atitudes" ${ }^{19}$. Essas pressões pedagógicas não apareciam nos manuais de civilidade e de "bons costumes" vindos da Europa, nos almanaques de farmácia, mas tecida e reproduzida na cultura do corpo familiar, nas reunióes entre amigos, nas fazendas e nas cocheiras onde o gado comia. Eram outras formas de transmissão de valores, de costumes, de gramáticas locais.

O homem atribuía uma grande importância ao ato de ferrar e à marca, não apenas como signo da família, mas como signo da sua própria honra e da cultura local, reproduzindo uma tradição da época do Brasil colônia. Honrar as calças que vestia, os fios de bigode e, acima de tudo, o nome da família, uma marca quase sagrada, uma herança sentimental. Daí a marca de ferrar não vir estampada apenas no couro do animal, mas em uma série de objetos que propagavam ainda mais a propriedade particular da família: "O ferro do cidadão tanto tinha valia em papel como em couro de bicho, móveis, queijos de manteiga, formas de rapadura, arreios, panos, chocalhos"20, constituindo-se um patrimônio afetivo e de reconhecimento de propriedade, uma tradição inventada para cada núcleo familiar. Nas reses e nos objetos, a marca do ferro do cidadão "tinha o valimento de sua assinatura e posse". Complementa Faria que, dessa forma, "ferrar era que nem assinar, marcar, firmar a posse de cada coisa e dar as provas do que lhe pertencia. E o ferro do cidadão tanto tinha valia em papel como em couro de bicho, móveis, arreios, panos, chocalhos e, em areias das pancadas do mar, até em pés de pau" ${ }^{\prime 2}$.

O dono se reconhecia e se fazia reconhecer através de suas marcas. Que Deus o livrasse de um dia não ter forças suficientes para derrubar a rês e torná-la submissa! Se isto acontecesse, o homem ficaria envergonhado, mofino, molenga, sem ânimo para enfrentar os seus pares, sem conversa, sem alegria, pois fora vencido pela força do animal. O que falariam dele? Que estava descalibrado, frouxo, negando fogo, ruim de ferrão. Que vergonha para um homem que carrega em si todo um estereótipo de valentão, de machão, cuja dureza é comparada aos mourões das porteiras das

\footnotetext{
${ }^{18}$ ROCHA-COUTINHO, Maria Lúcia. Tecendo por trás dos panos. Rio de Janeiro: Rocco, 1994, p. 55.

${ }^{19}$ ROCHA-COUTINHO, Tecendo por trás..., p. 56.

${ }^{20}$ MAIA, De iniciação à heráldica..., p. 33.

${ }^{21}$ FARIA, Ferros de Ribeiras, p. 24.
} 
fazendas em que morava! Portanto, derrubar a rês e marcá-la era uma forma de ocultar as fragilidades inerentes ao ser masculino.

$\mathrm{O}$ poeta nordestino utilizou uma série de metáforas que podemos associar, também, à masculinidade e ao mandonismo nordestinos. A masculinidade tecida nas noites escuras associa-se, em poesias nordestinas, às cavalgadas em que os animais empinam o "nome medonho" do seu dono:

\author{
Cavalo de noite, tecido de escuro \\ Sem sela, sem peia, sem cilha, sem medo, \\ Cavalo de treva, forjado em segredo, \\ Marcado nas ancas do fogo mais puro \\ Da têmpera a sangue, do avanço mais duro \\ Fareja peleja de estranho avatar \\ Rodeia vinganças de eterno rondar, \\ E o nome medonho que empina e releva \\ Disfarça na sombra, cavalo de treva, \\ Voando galope na beira do mar. ${ }^{22}$
}

No início do século XX, quando as oligarquias do Nordeste sofriam um choque provocado pela modernidade, e quando o modelo tradicional de família e de masculinidade começou a ser posto à prova, muitos discursos emergiram cantando loas ao perfil de macheza carregado por esse "homem valente" nordestino. Essas rupturas moleculares provocadas pela modernidade favoreceram a emergência de uma produção discursiva que repensa a família, surgindo uma linguagem voltada para as condições em que ela vivia econômica, política e culturalmente. Numa família assentada no masculino, os homens procuravam se proteger o tempo inteiro para não ver ameaçada a sua posição hierárquica. Nos discursos que circulam nesse contexto (literatura, discursos jornalísticos, preleções religiosas, dentre outros) há o esboço de uma rostidade familiar marcada pela verticalização dos sexos, sendo o masculino visto e dito como o "todo poderoso".

Essa abordagem histórico-antropológica objetiva instituir um espaço discursivo para esse modelo de família, uma origem para esses homens "másculos", agora em declínio. Uma família cujo perfil social tenha sido elaborado pelas relações do homem com a terra, com os animais, nascido e forjado seu caráter nacional em contato com o meio e com a terra. Até então, o modelo tradicional das relações entre homens $e$ mulheres, e entre homens e homens, não tinha sido fortemente questionado, nem se formularam perguntas sobre como são construídas as identidades femininas $e$ masculinas. Porém, com o advento do feminismo e do pensamento dito moderno determinadas mudanças emergem socialmente, momento em que os papéis $e$ identidades de gênero são colocados em questão, criando o que vários autores têm descrito como uma crise de identidade masculina ${ }^{23}$.

${ }^{22}$ OLIVEIRA, Sílvio Roberto de. Modo Nordeste. Rio de Janeiro: Conselho Municipal de Cultura, 1984, s./p.

${ }^{23}$ ALBUQUERQUE JR., Durval Muniz de. O nordestino e a invenção do falo. Maceió: Catavento, 2003; TROYA, "Clase media de...". 
No Nordeste, no início do século XX, o pressuposto de novos valores ainda é incipiente; as alterações não são rupturas definitivas nas formas de pensar o corpo $e$ a família, porém esse discurso que, embora seja ainda é tímido, assusta. Com o surgimento da produção discursiva modernista e dos hábitos ditos e vistos como burgueses, era mister criar uma referência para a família que habitava a geografia Nordeste, para que, através dela, se pensasse o "regional", a "cultura regionalista", as identidades nordestinas com suas caras, seus modos $e$, sobretudo, sua linguagem estereotipada.

A masculinidade do nordestino, presente nos discursos de cunho regionalistastradicionalistas, a exemplo do poema citado anteriormente, é tecida nas trevas de uma sociedade que está pondo às claras o modelo de dominação $e$ a predominância da família dita patriarcal. Tendo que lutar constantemente para provar sua masculinidade, de corpo esguio forjado na labuta do cotidiano, esse homem vive um constante dilema: precisa mostrar que é homem no peito e na raça e, para isso, necessita cortar toda ligação afetuosa com o ser feminino (considerado frágil $e$ delicado) e construir uma identidade balizada em estereótipos reproduzidos social $e$ culturalmente. Assim, emerge um conjunto de imagens associando esse homem a animais: o cavalo aloprado, rude, marcado a ferro nas ancas, um "cabra" macho, um galo de briga, um touro, um pai-de-chiqueiro, um burro-mulo. Mas por que "cabra" macho, já que cabra é um substantivo feminino?

Para ser macho, diz o poema, o homem constrói imagens nas noites silenciosas, enegrecidas, envolto à escuridão da vida, pois o dia pode revelar as suas fraquezas, a sua docilidade, os seus traços de sensibilidade feminina. Sua identidade é tecida no escuro e, nessa escuridão, o homem diz não precisar da sela, da peia, da cilha, das amarras que lhe prendem a outro corpo, a outros sujeitos. É à noite que ele pode ser livre, desamarrando o capital simbólico (peia, cilha, sela, arreio, medo, corpos) que fere sua rudeza e sua macheza e lhe dá um tom mais feminino. Sua identidade é semelhante à de um "cavalo de treva", pois é nessa penumbra que sua masculinidade está segura. A aurora pode quebrar seu ritmo de dominador, daí ele "disfarçar na sombra" ao criar todo um modo de vida de representação, de vigilância e de punição. A modernidade, representando a "grande aurora", emergiu para questionar e por à prova o modelo de identidade masculina tradicional e hegemônico, colocando em risco o ser homem no Nordeste, conforme analisa Albuquerque Júnior ${ }^{24}$.

As marcas do ferro tradicional deixavam de ser eretas e começavam a se tornar impotentes, a se desvirilizarem nas ancas da modernidade. O ser homem passou a ser um problema histórico, com posturas vigiadas, com gestos observados, com desvios punidos. O homem de família teve, então, que usar peia, cilha, arreio, a viver amarrado e com medo de não provar sua rudeza em todo tempo. A modernidade, em forma de mulher, pôs à prova o ferrão do homem regional $e$ as suas marcas de propriedade. A marca legitimava o dono da mesma, era uma escritura de si, uma assinatura de si que lhe nomeava, uma autografia que estabelecia um signo de propriedade nas ancas da rês e revelava a identidade do seu possuidor. Com a modernidade desconstruindo o arraial patriarcal, os homens sentiram-se envoltos num mundo ambíguo, numa identidade ambígua, oscilando entre as clarezas da

${ }^{24}$ ALBUQUERQUE JR., O nordestino e a invenção...

SAECULUM - Revista de História [37]; João Pessoa, jul./ dez. 2017. 
modernidade e a penumbra da tradição. O pensamento moderno estabeleceu uma ruptura ao criar a figura do masculino baseada na aparência física, no porte esbelto, na beleza e, por outro lado, a morfologia de um homem (ou uma mulher) determinado por sua virtude, honra e costumes.

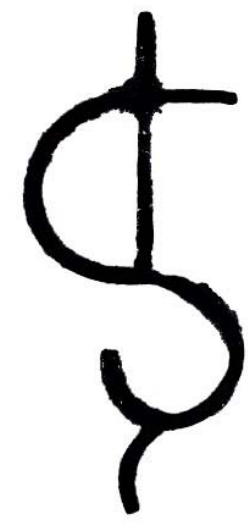

Fig. 1 - Marca de ferrar gado usada por Virgílio Maia.

$\mathrm{O}$ "S", com uma "flor" e uma haste vertical, foi a marca usada por tempos quando Virgílio Maia criou gado em Limoeiro do Norte-CE. Ferro herdado do trisavô Manuel Fidélis Costa. Um vaqueiro que viveu pelas bandas de São Bernardo, hoje Russas, que abarcava o território de onde se esquadrinha Limoeiro.

Fonte: jornal O Povo, 2014.

$\mathrm{O}$ ato de ferrar possui um conjunto de simbologias. Quem ferra é o homem, geralmente de porte mais forte, altivo, destemido, que torce a cauda dos animais e os faz cair, passivos e presos. O curral torna-se um teatro, um espaço de enfrentamento de forças entre os homens e entre o homem e o animal. Nessa teatralização, o gado era laçado no curral, "um a um derrubado a muque e imobilizado - pé e mãos amarrados com arreiadores de cabelo ou couro-cru"25. Sobre tal teatralização, Lamartine de Faria narra que, "enquanto um 'homem' quebrava a cauda e forçava com o joelho o vazio de cada rês para ela não espernear, o outro alisava o pêlo, sentava a marca cadente, com a mão maneira - um pouco mais que o peso do próprio ferro" 26 .

Ao cair o animal, o derrubador orgulha-se de sua potência e criatividade. Passivo ao cair, o animal torna-se apenas uma sombra diante dos olhos do seu viril possuidor que, de arma em punho esquentada no fogo a lenha, aponta a haste comprida $e$ quente, confeccionada de ferro batido forjado nas tendas dos ferreiros ${ }^{27}$, em direção ao couro cabeludo. Vencida pela força dos homens, o animal assiste o espetáculo da dominação $e$ assusta-se quando o ferro sai do fogo em brasa em sua direção, empunhado pelo vaqueiro. "Vista arregalada, a íris querendo se desgarrar do branco do olho, as arrobas do corpo sem chances de reagir". Deitada à força no areal do

${ }^{25}$ FARIA, Ferros de Ribeiras, p. 29.

${ }^{26}$ FARIA, Ferros de Ribeiras, p. 29.

${ }^{27}$ Do lado de fora do curral, outro vaqueiro fica responsável para cuidar da fogueira, deixando em brasa os ferros. Este passa, quando solicitado, o ferro ardente ao responsável pela feitura da marca. FARIA, Ferros de Ribeiras, p. 29-33. 
curral por três ou quatro peões, a rês "berra e bufa, esperneia. Vai estrebuchar mais quando a brasa lhe arder a carne" ${ }^{28}$, com a língua de fora e as pernas esmorecidas, sentido o cheiro de cabelo e de couro queimados. O historiador Danilo Patrício complementa essa descrição de Cláudio Ribeiro com as suas memórias de infância:

Preso no breque, encurralado entre a madeira e os outros bois, o bicho se batia esticando o pescoço, quando o estrebuchar já havia sido inútil ante o ferro quente letrado na pele. Era a marca do homem chegando, provocando um som de dor e de raiva no gado marcado. Berro seco. ${ }^{29}$

Do couro meio assado sobe fumaça, exibe, ainda em carne viva, identificações. Exalando, ainda, o cheiro da pelagem queimada, o ferrador passava estrume fresco na queimadura "para que descascasse sem virar ferida nem tomar bicho"30. Dali, a família e parte da sua história desenham-se para sempre no bicho ${ }^{31}$. O sangue da rês mistura-se ao sangue do seu dono. Depois do ritual de ferração, levanta-se com o corpo adulterado, ferido, sangrando, marcado, ardendo, profanado pela marca do seu senhor, pelo ferro polifônico e incandescente. Com essa atitude, o animal ferrado está pronto para representar o seu "legítimo" dono: não é mais um só corpo, são dois. Um real e outro simbólico. Não será mais identificada somente pela cor, pela raça, mas pela grafia do seu senhor tatuada em seu corpo. Instala-se nessa imagem uma figuração sádica, em que a dor do objeto representa o gozo do sujeito, ao mesmo tempo que representa, também, uma economia afetiva.

\section{Violência e Masculinidades: Performances}

$\mathrm{O}$ ato de ferrar aponta para a metáfora da masculinidade, entendida como uma atividade rude e própria do homem macho. O ato de ferrar é uma performance pública de mostrar sua masculinidade. Não é qualquer molenga que ferra o animal, mas um tipo de homem considerado brabo e corajoso, de físico resistente $e$ mesomorfo, capaz de tornar passivo seu objeto de ferração. É um ato imperioso e bestial, em que o ferrador orgulha-se diante do gesto submisso do seu objeto. Unindo a questão do significado à do poder, percebemos que ferrar gado fala de uma codificação e de uma distinção entre os corpos masculino e feminino, entre a dominação e a subjugação, a atividade e a passividade, elaborando toda uma gramática de força e atividade dos órgãos sexuais masculinos em contraposição à "debilitada" anatomia feminina. É importante essa distinção entre atividade/ passividade, dominação/ subjugação, pois é particularmente clara na linguagem utilizada para descrever o ato de ferrar, pois funciona metaforicamente para descrever

\footnotetext{
${ }^{28}$ RIBEIRO, Cláudio. "Donos de gado e de gente". O Povo, Caderno Especial "Sertão a ferro e fogo", Fortaleza, 11 ago. 2014.

${ }^{29}$ PATRÍCIO, Danilo. "Fogueiras acesas". O Povo, Caderno Especial "Sertão a ferro e fogo", Fortaleza, 11 ago. 2014.

${ }^{30}$ FARIA, Ferros de Ribeiras, p. 29.

${ }^{31}$ RIBEIRO, "Donos de gado e...".
} 
o ato de penetração do órgão sexual masculino no feminino, implicando, também, um ato de controle, de dominação, de atividade. Essas metáforas codificam, ainda, um sistema de valores culturais, um conjunto de relacionamentos sociais. Segundo Parker, desenvolvem "um campo de poder e organiza esse campo em torno dos polos de atividade e passividade definidos culturalmente, os quais se traduzem em noções muito contrastantes de masculinidade e feminilidade" ${ }^{\prime 2}$.

A violência - física e simbólica - inscrita no ato de marcar com ferro é tão forte que muitas vezes "cega" o homem, não o fazendo enxergar os seus limites e de incorporar esse estereótipo socialmente construído. No Estado de Alagoas, em setembro de 1984, o "cabra da peste" José Celestino ferrou o rosto de sua esposa, Maria Lúcia dos Santos, com um ferro em brasa. O jornal Tribuna Operária documentou esse ato como uma estupenda notícia, mas sequer salientou a marca de dominação masculina muito mais presente na sociedade nordestina do que no rosto de Maria Lúcia, traçando um perfil do masculino nordestino como um ser que possui um caráter mal $e$ uma "natureza traiçoeira", que precisa muitas vezes recorrer à violência para afirmar a sua condição de macho ${ }^{33}$. No discurso gestado pelo jornal, a violência aparece como um dos componentes da sociabilidade nordestina, uma característica imanente $e$ natural ao ser inventado no início do século XX para habitar a região Nordeste, recém elaborada, cartografada sentimentalmente como o "território da revolta" e da insubmissão ${ }^{34}$.

O ferro de marcar gado é um objeto alongado, agressivo, uma arma empunhada que está ligada à violência física $e$ à violação de $\operatorname{corpos}^{35}$. Há todo um jogo de vocábulos associados ao ferro, tais como tronco, haste, linha reta. O falocentrismo no ato de ferrar o gado remete à virilidade ${ }^{36}$ masculina. Instrumentos e gestos agressivos são constantes nesse momento, que combina o correr atrás da rês, derrubá-la ao chão, imobilizá-la, penetrar o seu couro. Quanto mais profunda for a penetração do ferro, mais visível será a marca registrada do seu dono, do signo da propriedade. Os que virem esse código perceberão a agressividade do ferrão $e$ a passividade do objeto de ferração. Tem que ser forte para ferrar, pois o homem considerado frouxo não irá se meter em tal serviço que exige aventura, experiência, violência e violação. Exige bravura, mas também inclui riscos, como coices, chifradas e perfurações no corpo do ferrador. É um ato em que o homem se afirma como macho e demonstra sua força física aos olhos de outros homens presentes e de mulheres que, de longe, o observam. E isto é importante, já que ele conseguiu mostrar sua fibra e garra perante outros homens do seu grupo. Assim, como a marca de ferrar, os ferradores são "rudes brasões" diante dos seus pares.

É através dessa e de outras estruturas de dominação simbólicas que vai se construindo e se constituindo dada visibilidade e certa dizibilidade para o corpo

32 PARKER, Richard G. Corpos, prazeres e paixões: a cultura sexual no Brasil. Tradução de Maria Therezinha M. Cavallari. 2. ed. Rio de Janeiro: Best Seller, 2013, p. 72.

${ }^{33}$ Tribuna Operária, Maceió, 3 a 9 set. 1984.

${ }^{34}$ ALBUQUERQUE JR., O engenho antimoderno...

35 BOURDIEU, Pierre. "A dominação masculina". Educação \& Realidade, Porto Alegre, vol. 20, n. 2, jul./dez. 1995, p. 133-184.

${ }^{36} \mathrm{~A}$ virilidade pode ser compreendida como a existência de diferentes graus de masculinidade, conforme estudam Andrade \& Herrera. 
masculino do nordestino, em particular, e da masculinidade brasileira como um todo. Toda uma linguagem simbólica é desenvolvida tendo como padronização o homem. São eles que dominam a arte de ferrar. É mediante essas estruturas "que a realidade percebida do corpo masculino é culturalmente elaborada e articulada", que os diversos sentidos "associados com masculinidade na cultura brasileira fundem-se e se entrelaçam" 37 . Os discursos tradicionais sobre o gênero vão demarcando espaços, criando fronteiras, estigmatizando territórios, cartografando o desejo:

Os padrões tradicionais definidos pelo modelo patriarcal para o comportamento masculino dissimulam as possibilidades do encontro nas relações sociais, pois definem que em uma relação, a priori, alguém ataca e alguém defende, alguém ganha e alguém perde. Esta concepção de relação impossibilita o estabelecimento de qualquer tipo de contato fora das fronteiras demarcadas pela moral patriarcal, que em última instância faz crer aos homens que estão continuamente expostos ao ataque. Assim, desde pequenos os homens aprendem esta regra, transformando-a posteriormente em uma crença de que as atitudes combativas e agressivas incorporadas pelos homens são atributos biológicos. ${ }^{38}$

Percebe-se, portanto, uma geografia sentimental e um jogo de capital simbólico nas marcas de ferrar gado. A identidade da família, do "dono da casa", do pater família, vai sendo forjada de ferro em ferro, de marca em marca, a cada couro queimado, em cada pedaço de carne violado, estigmatizado, emblematizado, violentado. Figuras de uma dominação masculina, flâmulas de uma identidade gestada no âmbito das culturas locais e das histórias que transitam no cotidiano familiar: identidades de gênero, sexuais, de pertencimento a um pedaço da geografia chamado Nordeste, identidades de classe, de posição social. Essas distintas identidades vão constituindo os sujeitos que também foram inventados para habitar esse espaço geográfico.

Com o reconhecimento dessa identidade singular, esse conjunto de homens do Nordeste (que, diga-se, não é qualquer homem do Nordeste que reconhece essa identidade) vai responder afirmativamente aos estereótipos criados e propagados para si e estabelecer um sentido de pertencimento a um grupo social de referência. Essa identificação com um determinado grupo social de referência estabelece, ao mesmo tempo, um sistema de diferenciação, de hierarquias, de atribuições. Implica a constituição de desigualdades, de ordenamentos, estreitamente imbricados, segundo Louro ${ }^{39}$, com as redes de poder que circulam numa certa comunidade ou sociedade. Ao reconhecer o "outro" como desigual, como diferente, como não compartilhando dos mesmos valores e dos mesmos atributos e dotes, é institucionalizado no seio do

\footnotetext{
${ }^{37}$ PARKER, Corpos, prazeres e paixões..., p. 67.

${ }^{38}$ NOLASCO, Sócrates Álvares. "O masculino: um dilema contemporâneo?". In: O mito $d a$ masculinidade. 2 ed. Rio de Janeiro: Rocco, 1993, p. 43.

${ }^{39}$ LOURO, Guacira Lopes. O corpo educado. Belo Horizonte: Autêntica, 2013, p. 15.
} 
grupo e da sociedade um processo de discriminação, de diferenciação, de estranhamento. Cada corpo vai sendo circunscrito num determinado estereótipo, cartografado com uma dada identidade, reconhecido pelas impressões externas $e$ internas que lhe são subjacentes.

A sociedade, portanto, treina seus sentidos para perceber e decodificar as marcas $e$ cheiros de cada corpo, os sons que saem de cada sujeito, para depois classificá-los e estereotipá-los pelas maneiras como se apresentam corporal e linguisticamente, pelos comportamentos e gestos que utilizam e pelas diversas maneiras com que se expressam. Ao realizar o processo de classificação e estereotipia, a sociedade começa a construir os contornos e demarcar as fronteiras do ser homem no Nordeste, delimitando os espaços que representam a norma (os signos que estão em consonância com os seus padrões culturais) $e$ aqueles que codificam a transgressão, o patológico, o marginal. É, dessa forma, que o homem nordestino constituído nas primeiras décadas do século XX vai ser estereotipado, visto e propagado como o "cabra da peste" que não leva desaforo para casa; como o pater famílias que provê, mesmo através da violência, do saque e do roubo, o pão cotidiano; como o fornido homem, de músculos masculinizados, roliços, que defende as mulheres no peito e na raça. Ele é, acima de qualquer suspeita, um homem forte, viril, potente na cama, na mesa e na roça, católico (embora fira os dogmas da religiosidade ao usar da violência $e$ da transgressão para assumir a sua macheza) $e$ aventureiro.

Foram essas algumas marcas definidoras das identidades masculinas, legitimadas (inclusive o uso da violência e da violação de corpos) pela sociedade na qual está inserido. Os demais sujeitos são rotulados, definidos e denominados a partir dessa referência. Paulatinamente, torna-se perceptível a invenção e propagação de uma identidade elaborada para dominar e de outras historicamente subjugadas. Para todos que se reconhecem nesse campo de forças, assumir a condição de dominador ou de subjugado é um ato político e, também, uma atitude que pode sentir na pele o alto preço da estigmatização, da estereotipia. Para Louro:

Os grupos sociais que ocupam as posições centrais, "normais (de gênero, de sexualidade, de raça, de classe, de religião, etc) têm possibilidade não apenas de representar a si mesmos, mas também de representar os outros. Eles falam por si e também falam pelos "outros" (e sobre os outros); apresentam como padrão sua prática estética, sua ética ou sua ciência e arrogam-se o direito de representar (pela negação ou pela subordinação) as manifestações dos demais grupos. Por tudo isso, podemos afirmar que as identidades sociais $e$ culturais são políticas. ${ }^{40}$

Dessa forma, a educação do homem nordestino responde a um projeto bem amplo - a construção do Nordeste - e, para tanto, é necessário que seja elaborada uma determinada forma de ser masculino: uma masculinidade tecida em circunstâncias agressivas, duras, forjadas na competição, no risco, na aventura, na

${ }^{40}$ LOURO, O corpo educado, p. 16. 
violência consentida e legitimada, nas brigas nos salóes de baile, nos campos de futebol, nas argolinhas, nos assustados ${ }^{41}$, nas disputas por terras e por bens. Desde criança, o "menino-macho" é ensinado, disciplinado, medido, avaliado, examinado, categorizado, coagido, magoado, punido.

O propósito dessa disciplinarização e da educação de corpos, de todos esses investimentos, era a educação de um homem que se adequasse às normas estabelecidas culturalmente e que se adaptasse ao pedaço regional Nordeste: seco, áspero, agressivo, rude, caliente. Para habitar esse espaço, era preciso gestar um sujeito capaz de viver em coerência e adequação a esses dados "naturais". A regionalidade patriarcal em crise exigia, pois, a definição de um homem que apresentasse marcas visíveis desse processo de masculinização: marcas que deveriam ser valorizadas pela sociedade e servisse como referência na educação de outros indivíduos. A mulher, por sua vez, precisava constantemente da força deste homem, da sua proteção, do seu cuidado. A mulher necessitava, para sobreviver, de um homem desses e, se o rejeitasse, ela mesma deveria adquirir o perfil masculino, tornando-se uma mulher-macho, uma Luzia-Homem. ${ }^{42} \mathrm{Na}$ educação de mulheres $e$ de homens, mesmo que isso não apareça de forma evidente e transparente, "há um investimento continuado e produtivo dos próprios sujeitos na determinação de suas formas de ser ou 'jeitos de viver' sua sexualidade e seu gênero" 43 .

Para adestrarem os seus corpos quanto a essa maneira de viver a sua sexualidade, de sentir o seu corpo, há uma forte educação dos sentidos. Conforme Foucault, "o domínio e a consciência de seu próprio corpo só puderam ser adquiridos pelo efeito do investimento do corpo pelo poder: a ginástica, os exercícios, o desenvolvimento muscular, a nudez, a exaltação do belo corpo" ${ }^{44}$. Há, nessa sociedade, uma demarcação nítida entre os papéis masculinos e femininos, no comportamento do homem em ambas as esferas, pública e privada e, no seio desse projeto colonizador, existe um interesse no policiamento público e privado da sexualidade e da masculinidade.

\section{Considerações Finais}

Estudar as dinâmicas de masculinidades presentes no ritual de ferração de gado nas primeiras décadas do século XX, no Nordeste constitui, em maior ou menor grau, uma estratégia para problematizar as identidades de gênero como construções conflitantes e ambíguas, em vez de linear e precisa. É uma estratégia, também, para aprofundar as pesquisas acerca da dinâmica de poder nas relações de gênero, bem como de problematizar os papeis sociais que se constroem histórica e culturalmente. Assim, compreendemos que as identidades masculinas são entendidas como produto

\footnotetext{
${ }^{41}$ Festas populares e familiar com dança, música e bebidas, muito comuns nas pequenas cidades e zonas rurais do Nordeste até os anos 70 do século XX. Também chamadas de pequenos bailes ou bailaricos.

${ }^{42}$ As características masculinas do personagem Luzia-Homem estão descritas no romance homônimo do escritor cearense Domingos Olímpio, publicado em 1903.

${ }^{43}$ LOURO, O corpo educado, p. 26.

${ }^{44}$ FOUCAULT, Michel. Microfísica do poder. Organização e tradução de Roberto. Machado. 11. ed. Rio de Janeiro: Graal, 1993, p. 146.
} 
de uma ordem cultural que define tanto o sistema de dominação entre os sexos como hierarquias e responsabilidades entre os homens ${ }^{45}$.

Problematizar esta desnaturação da masculinidade constitui uma possibilidade de repensar a relação dos homens no interior das famílias do Nordeste, as desigualdades entre o masculino e o feminino, a dominação masculina presente nos homens e nas mulheres, bem como a emergência de novas formas de pensar o corpo, a família e a sociedade, as mudanças culturais a partir dos anos 40, nas quais o fogo e outras marcas dos "ferros de patriarcas" já "não prevalecem mais" ${ }^{6}$ !

\section{$\operatorname{son}$}

\section{RESUMO}

Este artigo analisa a construção da masculinidade nas primeiras décadas do século XX, no Nordeste brasileiro, a partir da prática da ferração do gado e do uso do corpo pelos homens nas fazendas, tendo como fontes as marcas de ferrar gado e o ritual da ferração como textualidades culturais que permitem compreender as representações que homens $e$ mulheres tecem sobre si e sobre o outro. O ritual da ferração constitui um conjunto de ações que permitem aos homens usarem o seu corpo como um texto no qual outros sujeitos podem ler suas expressões de masculinidade $e$ virilidade. Inscritas no corpo, tais práticas precisam ser reforçadas cotidianamente através de outras gramáticas, como a linguagem, a relação com outros homens e mulheres e o respeito aos códigos de honra familiar. A análise envolve as práticas familiares e socioculturais, pois abordar o problema do masculino é considerá-lo como parte das relações tecidas socialmente, incluindo um conjunto de discursos religiosos, políticos, cívicos e regionais, todos como processos pedagógicos e tecnologias educativas de homens e de mulheres.

Palavras Chave: Marcas de Ferrar Gado; Masculinidades; Nordeste Brasileiro.

\begin{abstract}
This paper analyzes the construction of masculinity in the first decades of the twentieth century, in the Brazilian Northeast, from the practice of the tagging of the cattle and the use of the body by the men in the farms, having as sources the brands of sign the cattle and the ritual of the tagging like Cultural textualities that allow to understand the representations that men and women weave on themselves and on the other. The ritual of marking in hot iron is a set of actions that allow men to use their body as a text in which other subjects can read their expressions of masculinity and virility. Inscribed in the body, such practices need to be reinforced daily through other grammars such as language, relationships with other men and women, and respect for family honor codes. The analysis involves family and sociocultural practices, since addressing the problem of the masculine is to consider it as part of the socially woven relations, including a set of religious, political, civic and regional discourses, all as pedagogical processes and educational technologies of men and women.
\end{abstract}

Keywords: Brands of Sign Cattle; Masculinities; Brazilian Northeast.

Artigo recebido em 22 mai. 2017.

Aprovado em 07 jul. 2017.

\footnotetext{
${ }^{45}$ GREIG, Alan; KIMEL, Michael \& LANG, James. "Men, masculinities and development: broadening our work towards gender equality". Gender in Development Monograph Series, n. 10, mai. 2000, p. 5.

${ }^{46}$ MENEZES, Othoniel apud "A FLORAÇÃO das craibeiras". Tribuna do Norte, Natal, 04 set. 2011.
} 